\title{
Critical Metal Mineralogy: Preface to the special issue of Mineralogical Magazine
}

\section{K.M. Goodenough ${ }^{1}$ \& F. Wall ${ }^{2}$}

1: British Geological Survey, The Lyell Centre, Research Avenue South, Edinburgh EH14 4AP, UK

2: Camborne School of Mines, University of Exeter, Penryn Campus, Penryn, TR10 9FE, UK

The phrase 'critical metals' has become widely used over the last decade. Critical metals are those for which demand is increasing, largely due to their use in new technologies, but for which there are restrictions to supply. These supply restrictions are normally not due to a natural shortage of these elements, but instead can principally be attributed to a concentration of production in a small number of countries. Markets for many of the critical metals are still small when compared with those for major industrial metals such as copper or lead, and at the time of writing prices for almost all metals are low; as a result it can be difficult to diversify production. A number of reports, books and special issues have been published on the subject (Graedel et al., 2012, EC, 2014, Gunn, 2014, Chakhmouradian et al., 2015, Lusty and Gunn, 2015, Graedel et al., 2015).

There is no single definitive list of critical metals, because the exact definition varies according to the context and the author. The designation of a metal as critical can also change with time, as prices and demand vary. One of the most widely accepted lists of critical raw materials is that published by the European Commission (EC, 2014). This list recognises the rare earth elements (REE), particularly the heavy REE (HREE), as among the most critical of all raw materials, because they are vital components of the high-strength magnets and phosphors that are widely used in many modern technologies. Other metals recognised as critical by the EC include tungsten, antimony, niobium, magnesium and cobalt. Lithium may also be considered as critical (Evans, 2014), and is notable for consistently growing demand, due to its importance in batteries used in electric cars (Vikström et al., 2013, Maxwell, 2014). A metal that is on the verge of criticality is manganese, which is a crucial raw material for the steel industry. Demand for manganese has shown growth in recent years, and there is some vulnerability to supply restriction (Nuss et al., 2014, Graedel et al., 2015).

Geological resources of critical metals are commonly found in complex natural systems that are not always well understood. These metals occur in a wide range of ore minerals with highly varied properties. For example, more than a hundred potential REE ore minerals occur in nature, although processing methods for beneficiation, extraction and separation of the REE have only been proven for a relatively small number of these minerals (Chakhmouradian and Wall, 2012, Jordens et al., 2013). Before any critical metal deposit can move towards production, it is vital to understand the mineralogy in detail, as this underpins development of flowsheets for mineral processing (Jordens et al., 2013). This special issue therefore addresses the mineralogy of critical metal deposits. Most of the papers included here were first presented in 2014, either at the European Rare Earth Resources conference in Milos, Greece, or at the 21st General Meeting of the International Mineralogical Association in Johannesburg, South Africa.

Despite a significant focus on research and exploration since the 'rare earths crisis' of 2009-10 (Gschneidner Jr, 2011), REE production is still almost entirely concentrated in China, and the REE are still considered among the most critical metals. The majority of the world's light REE (LREE) come from the Bayan Obo carbonatite mine in northern China, whilst almost all the HREE come from the 
ion-adsorption clays of southern China (Kynicky et al., 2012). Several of the papers in this volume address the potential for alternative sources of the REE across the world. In a global context, some of the world's largest identified REE resources are found in the Ilimaussaq complex of southern Greenland (Sørensen, 1992), which hosts two advanced exploration projects, Kringlerne and Kvanefjeld (Goodenough et al., 2016). Of these, the Kringlerne prospect lies within a zone of layered agpaitic nepheline syenites in which the REE are largely hosted in eudialyte-group minerals. In this volume, Borst et al. (2016) show that a high percentage of these minerals have in fact been hydrothermally altered and replaced by a range of other mineral assemblages. They provide detailed descriptions of these assemblages, including the first recognition of gittinsite as an alteration product of eudialyte, and show that fluid compositions have a significant effect on the alteration mineral assemblage formed. REE are most typically retained within the pseudomorphs. However, the authors note that the alteration assemblages may have different properties to the original eudialyte-group minerals, and thus this may have significant implications for mineral processing.

Research presented here by Friis (2016) also studies alteration and mineral replacement in the Ilimaussaq complex, using samples from Kvanefjeld. This work provides the first description of moskvinite-( $(Y)$ in llimaussaq, and shows that alteration of original REE minerals can lead to fractionation of the LREE from the HREE, producing pseudomorphs that include both LREE minerals such as britholite-(Ce) and HREE minerals such as moskvinite-(Y). As at Kringlerne (Borst et al. 2016) it is evident that the REE are retained within the boundaries of the original crystal, despite the change in mineralogy.

Mining and processing of the REE from hard-rock sources is highly energy-intensive, with the need for blasting, crushing and milling of the rock, followed by complex beneficiation procedures to concentrate the REE ore minerals. In order to reduce energy usage and thus environmental impacts, research into alternative REE sources is developing. Deady et al. (2016) investigate the potential for REE resources in red muds, the waste products of aluminium production, which are currently stockpiled across Europe. Using case studies from Greece and Turkey, they review the mineralogy and REE geochemistry of the bauxite ores and the red muds produced from them. They show that REE are concentrated into the red muds during processing, and demonstrate that these waste red muds have significant potential as an REE resource for Europe.

Most of the world's HREE supply is currently derived from ion adsorption clays in China (Kynicky et al., 2012, Weng et al., 2015). The REE are typically recovered from these deposits through in-situ leaching processes, which are much less energy intensive than production from hard-rock deposits. The paper in this volume by Moldoveanu and Papangelakis (2016) provides an overview of leaching procedures for extraction of REE, as tested on a range of ion adsorption clay samples from different localities. Their work shows that tropically weathered clays from localities in South America, Africa and China are all easily leachable, indicating the presence of physically adsorbed REE on clay surfaces, and they have established benchmark procedures for leaching. They also show that only some ion adsorption-type ores are enriched in the HREE, suggesting a strong control by the original bedrock composition and mineralogy.

Exactly how original bedrock composition and mineralogy control the nature of the ion adsorption deposits is the subject of the paper by Sanematsu et al. (2016). They consider which minerals have controlled light versus heavy REE ratios during magmatic differentiation and weathering of calc- 
alkaline granites in southern Myanmar. They find that ion-exchangeable REE in weathered granites tend to be depleted in HREE relative to the whole-rock compositions, i.e. that the HREE are more likely to be held in insoluble residual minerals. Ion adsorption deposits may be economic at much lower concentrations than conventional deposits, and values as low as 500 ppm REE are of interest. However, the key to economic success is likely to be in finding deposits with sufficiently high proportions of the more expensive HREE and this will require soluble HREE-enriched minerals in the protolith.

Global lithium resources are typically found in brine deposits, particularly in South America, and in pegmatite deposits (Kesler et al., 2012). The paper in this volume by Roda-Robles et al (2016) provides an overview of one of Europe's main areas of lithium mineralisation, in the Iberian Massif of Spain and Portugal. The mineralisation here is associated with peraluminous granites and pegmatites of Variscan age, and is of significant economic importance: Portugal is now the world's $6^{\text {th }}$ largest lithium producer. Roda-Robles et al describe a range of potential Li ore minerals in these intrusions, including Li-micas, Li-aluminosilicates such as spodumene and petalite, and Li-phosphates of the amblygonite-montebrasite and triphylite-lithiophylite series. Classification of the intrusions into groups with varying Li content and different dominant minerals allows improvement of exploration targeting in the area.

Finally, as demand for manganese is growing, there is an interest in a wider range of deposit types. Zarasvandi et al. (2016) present a study of the manganese deposits associated with Tethyan ophiolites in Iran, and use their geochemistry to investigate their origin.

The guest editors, Kathryn Goodenough and Frances Wall, thank Roger Mitchell, Kevin Murphy and Helen Kerbey for their support in bringing together this thematic issue. The reviewers of the manuscripts are thanked for their constructive comments.

\section{References}

Chakhmouradian, A. R., Wall, F., 2012. Rare Earth Elements: Minerals, Mines, Magnets (and More). Elements 8, 333-340.

Chakhmouradian, A. R., Smith, M. P., Kynicky, J., 2015. From "strategic" tungsten to "green" neodymium: A century of critical metals at a glance. Ore Geology Reviews 64, 455-458.

EC. 2014. Report on Critical Raw Materials for the EU.

Evans, K., 2014. Lithium. In: Gunn, A. G. (ed.) Critical Metals Handbook. John Wiley \& Sons Ltd. Goodenough, K. M., Schilling, J., Jonsson, E., Kalvig, P., Charles, N., Tuduri, J., Deady, E. A., Sadeghi, M., Schiellerup, H., Müller, A., Bertrand, G., Arvanitidis, N., Eliopoulos, D. G., Shaw, R. A., Thrane, K., Keulen, N., 2016. Europe's rare earth element resource potential: An overview of REE metallogenetic provinces and their geodynamic setting. Ore Geology Reviews 72, Part 1, 838-856.

Graedel, T. E., Barr, R., Chandler, C., Chase, T., Choi, J., Christoffersen, L., Friedlander, E., Henly, C., Jun, C., Nassar, N. T., Schechner, D., Warren, S., Yang, M.-y., Zhu, C., 2012. Methodology of Metal Criticality Determination. Environmental Science \& Technology 46, 1063-1070.

Graedel, T. E., Harper, E. M., Nassar, N. T., Nuss, P., Reck, B. K., 2015. Criticality of metals and metalloids. Proceedings of the National Academy of Sciences 112, 4257-4262.

Gschneidner Jr, K. A., 2011. The rare earth crisis-the supply/demand situation for 2010-2015. Material Matters 6.

Gunn, G. (ed.) 2014. Critical Metals Handbook, Chichester: John Wiley \& Sons, Ltd. 
Jordens, A., Cheng, Y. P., Waters, K. E., 2013. A review of the beneficiation of rare earth element bearing minerals. Minerals Engineering 41, 97-114.

Kesler, S. E., Gruber, P. W., Medina, P. A., Keoleian, G. A., Everson, M. P., Wallington, T. J., 2012. Global lithium resources: Relative importance of pegmatite, brine and other deposits. Ore Geology Reviews 48, 55-69.

Kynicky, J., Smith, M. P., Xu, C., 2012. Diversity of Rare Earth Deposits: The Key Example of China. Elements 8, 361-367.

Lusty, P. A. J., Gunn, A. G., 2015. Challenges to global mineral resource security and options for future supply. Geological Society, London, Special Publications 393, 265-276.

Maxwell, P., 2014. Analysing the lithium industry: Demand, supply, and emerging developments. Mineral Economics 26, 97-106.

Nuss, P., Harper, E. M., Nassar, N. T., Reck, B. K., Graedel, T. E., 2014. Criticality of Iron and Its Principal Alloying Elements. Environmental Science \& Technology 48, 4171-4177.

Sørensen, H., 1992. Agpaitic nepheline syenites: a potential source of rare elements. Applied Geochemistry 7, 417-427.

Vikström, H., Davidsson, S., Höök, M., 2013. Lithium availability and future production outlooks. Applied Energy 110, 252-266.

Weng, Z., Jowitt, S. M., Mudd, G. M., Haque, N., 2015. A Detailed Assessment of Global Rare Earth Element Resources: Opportunities and Challenges. Economic Geology 110, 1925-1952. 